\title{
RADIO-SENSITIZATION OF HUMAN LEUKAEMIC MOLT-4 CELLS BY DNA-DEPENDENT PROTEIN KINASE INHIBITOR, NU7026
}

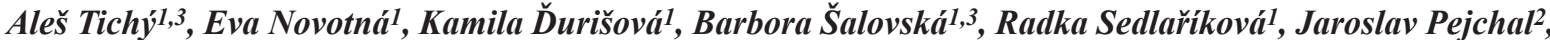 \\ Lenka Zárybnická1, Jiřina Vávrovál, Zuzana Šinkorová1, Martina Řezáčováa
}

University of Defence in Brno, Faculty of Health Sciences in Hradec Králové, Czech Republic: Department of Radiobiology ${ }^{1}$, Centrum of Advanced Studies ${ }^{2}$; Charles University in Prague, Faculty of Medicine in Hradec Králové, Czech Republic: Institute of Medical Biochemistry ${ }^{3}$

Summary: In this paper we describe the influence of NU7026, a specific inhibitor of DNA-dependent protein kinase, phosphoinositide 3-kinase, and ATM-kinase on molecular and cellular mechanisms triggered by ionising irradiation in human T-lymphocyte leukaemic MOLT-4 cells. We studied the effect of this inhibitor $(10 \mu \mathrm{M})$ combined with gammaradiation $(1 \mathrm{~Gy})$ leading to DNA damage response and induction of apoptosis. We used methods for apoptosis assessment (cell viability count and flow-cytometric analysis) and cell cycle analysis (DNA content measurement) and we detected expression and post-translational modifications (Western blotting) of proteins involved in DNA repair signalling pathways. Pre-treatment with NU7026 resulted into decreased activation of checkpoint kinase-2 (Thr $\left.{ }^{68}\right)$, p53 ( $\operatorname{Ser}^{15}$ and $\left.\mathrm{Ser}^{392}\right)$, and histone H2A.X ( $\mathrm{Ser}^{139}$ ) 2 hours after irradiation. Subsequently, combination of radiation and inhibitor led to decreased amount of cells in G2-phase arrest and into increased apoptosis after 72 hours. Our results indicate that in leukaemic cells the pre-incubation with inhibitor NU7026 followed by low doses of ionising radiation results in radio-sensitising of MOLT-4 cells via diminished DNA repair and delayed but pronounced apoptosis. This novel approach might offer new strategies in combined treatment of leukaemia diseases.

Key words: Inhibitor NU7026; DNA-PK; ATM, PI3-K; Ionizing radiation; Leukaemia; Apoptosis; Cell cycle

\section{Introduction}

Genotoxic agents such as ionising radiation (IR), UVlight or chemical pollutants trigger activation of a complex network of signal transduction pathways collectively referred to as the DNA damage response (31). Typically, double strand breaks (DSB) as one of the most severe forms of DNA damage arise and the signal is sensed and mediated to the effectors, which cause block of cell proliferation followed by DNA repair, senescence, or elimination of unwanted cells by engaging apoptosis.

The chief co-ordinators of the DSB signal are the nuclear protein kinases DNA-dependent protein kinase (DNA-PK) (2) and ataxia-telangiectasia mutated kinase (ATM) (20). DNA-PK is a member of the phosphoinositide 3-kinase-like enzyme family (33). This nuclear serine/ threonine protein kinase is required for repairing DSB and for $\mathrm{V}(\mathrm{D}) \mathrm{J}$ recombination. In multi-cellular eukaryotes, the predominant pathway for DSB repair involves a distinct end-joining pathway that requires little or no sequence homology (10). Four gene products required for this activity have been identified, and three of them correspond to the three subunits of DNA-PK, i.e. DNA-PK catalytic subunit (DNA-PK $\mathrm{CS}_{\mathrm{S}}$ ), Ku70, and Ku80 (reviewed in (2)). The fourth component, XRCC4, is a 55-60 kDa nuclear phosphoprotein that is ubiquitously expressed and forms tight complexes with DNA ligase IV (22).

ATM plays no doubt a crucial role in control of cellular responses to DSB, because it regulates all three cell cycle checkpoints, DNA repair, and apoptosis (19). After induction of DSB, it is rapidly activated by intermolecular autophosphorylation (3). ATM is also a member of the phosphoinositide 3-kinase-like enzyme family and it integrates the cellular response to DSB by phosphorylating key proteins involved in these processes, such as $\mathrm{p} 53$, murine-double minute protein (Mdm2), and checkpoint kinase-2 (chk-2) managing the G1 checkpoint and many others for the transient S-phase arrest and the G2/M checkpoint $(24,25)$.

Our understanding of how the irradiated cells sense DNA damage is still unclear but it is more than likely that DNA-PK and ATM are major signal transducers. Since the crucial DNA repair enzymes play a pivotal role in the recent cancer research, the discovery of their inhibitors is of a great interest too.

In this work we used a novel specific DNA-PK inhibitor, NU7026, which has been reported as a radio-sensitiser in vitro $(13,39,40)$. NU7026 (2-(morpholin-4-yl)-benzo(H) chromen-4-one) inhibits both DNA-PK and ATM but predominantly affects the former one $\left(\mathrm{IC}_{50}: 0.23 \mu \mathrm{M}\right.$ for 
DNA-PK, $13 \mu \mathrm{M}$ for phosphoinositide 3-kinase, and more than $100 \mu \mathrm{M}$ for ATM) (26).

IR is commonly used in cancer treatment in order to eliminate tumour cells by apoptosis. A wide range of kinase inhibitors is used intentionally to increase the cytotoxic effect of radiation. In our previous work, we showed that ATM/chk-2/p53 pathway is activated upon irradiation in human T-lymphocyte leukaemia cell line MOLT-4 (36). In this paper we report about the effect of NU7026 inhibitor combined with ionising radiation on activation of several components of DNA damage response signalling pathway (p53, chk-2, and H2A.X) and its influence on induction of apoptosis and cell cycle progress.

\section{Methods}

\section{Cell cultures and culture conditions}

MOLT-4 cells were obtained from the American Type Culture Collections (Manassas, VA, USA). The cells were cultured in Iscove's modified Dulbecco medium (Sigma, St. Louis, MO, USA) supplemented with $20 \%$ fetal calf serum, $0.05 \%$ L-glutamine, $150 \mathrm{UI} / \mathrm{ml}$ penicillin, $50 \mu \mathrm{g} / \mathrm{ml}$ streptomycin in a humidified atmosphere with $5 \% \mathrm{CO}_{2}$ at $37^{\circ} \mathrm{C}$. The cultures were split every second day by dilution to a concentration of $2 \times 10^{5}$ cells $/ \mathrm{ml}$. The cell counts were performed with a hemocytometer; the cell membrane integrity was determined by using the Trypan blue exclusion technique. Cell lines in the maximal range of up to 20 passages were used for this study.

\section{Gamma irradiation}

Exponentially growing MOLT-4 cells were suspended at a concentration of $2 \times 10^{5} / \mathrm{ml}$ and divided into four groups: control (intact cells), only NU7026 exposed cells, only irradiated cells and combined exposure. Aliquots of $10 \mathrm{ml}$ of cell suspension were plated into $25 \mathrm{~cm}^{2}$ flasks (Nunc, Wiesbaden, GER) and irradiated at room temperature using ${ }^{60} \mathrm{Co}$ gamma-ray source with a dose-rate of $0.4 \mathrm{~Gy} / \mathrm{min}$, at a distance of $1 \mathrm{~m}$ from the source. After the irradiation by the dose of $1 \mathrm{~Gy}$ the flasks were placed in a $37{ }^{\circ} \mathrm{C}$ incubator with $5 \% \mathrm{CO}_{2}$ and aliquots of the cells were taken at 2 or 24 hours after irradiation for analysis. The cells were counted and cell viability was determined with the Trypan blue exclusion assay.

\section{NU7026 inhibitor exposure}

We added $10 \mu \mathrm{M}$ NU7026 (Millipore, Billerica, MA USA) to the cells half an hour prior irradiation.

\section{Flow-cytometric analysis}

The cells were collected and washed with cold PBS (phosphate-buffered saline) and fixed in $70 \%$ ethanol. For the fixation of low molecular fragments of DNA the cells were incubated for $5 \mathrm{~min}$ at room temperature in a phosphate buffer and then stained with propidium iodide in the Vindelov's solution for $30 \mathrm{~min}$ at $37^{\circ} \mathrm{C}$. The fluorescence (DNA content) was measured with a Coulter Electronic (Hialeah, FL, USA) apparatus. A minimum of 10,000 cells analyzed in each sample served to determine the percentages of cells in each phase of the cell cycle, using the Multicycle AV software. Three independent experiments were performed.

\section{Electrophoresis and Western blotting}

At various times after irradiation, the MOLT- 4 cells were washed with PBS and lysed. Whole cell extracts were prepared by lysis in $500 \mu \mathrm{l}$ of lysis buffer $(137 \mathrm{mM} \mathrm{NaCl}$; $10 \%$ glycerol; $1 \%$ n-octyl- $\beta$-glucopyranoside; $50 \mathrm{mM}$ $\mathrm{NaF}$; $20 \mathrm{mM}$ Tris, $\mathrm{pH}=8 ; 1 \mathrm{mM} \mathrm{Na} \mathrm{VO}_{4} ; 1$ tablet of protein inhibitors Complete ${ }^{\mathrm{TM}}$ Mini, Roche). The lysates containing equal amount of protein $(30 \mu \mathrm{g})$ were loaded onto a $12 \%$ SDS polyacrylamide gel. After electrophoresis, proteins were transferred to a polyvinylidene difluoride membrane (BioRad, Hercules, CA, USA), and hybridized with an appropriate antibody: anti- $\gamma \mathrm{H} 2 \mathrm{~A} . \mathrm{X}\left(\mathrm{Ser}^{139}\right)$ and anti-Chk-2 (Thr $\left.{ }^{68}\right)$ from Cell Signaling, Chicago, IL, USA; anti-p53 and anti-p53 ( $\mathrm{Ser}^{392}$ ) from Exbio, Prague, CZE; anti-p53 (Ser $\left.{ }^{15}\right)$ from Calbiochem, San Diego, CA, USA. After washing, the blots were incubated with secondary peroxidase-conjugated antibody (Dako, High Wycombe, UK) and the signal was developed with ECL detection kit (BM Chemiluminescence - POD, Roche, Manheim, GER) by exposure to a film. The films were scanned and integrated optical density (IOD) was measured by ImagePro 1.0 software (Microsoft, Seattle, WA, USA).

\section{Statistical analysis}

The data were statistically analyzed by t-test using SigmaStat software (Aspire Software International, Ashburn, VA, USA). The significance level alpha was 0.025 .

\section{Results}

\section{Determination of proliferative activity}

Initially, we performed the cell count (cell membrane integrity was determined by using the Trypan blue exclusion technique). The number of living intact cells was analyzed 20, 70, and 140 hours after irradiation. The cell were pretreated with 5 or $10 \mu \mathrm{M}$ NU7026 solely or followed by exposure to 0.5 or 1 Gy. After 140 hours a partial growth inhibition was observed in the groups exposed to $1 \mathrm{~Gy}$ and those combining $5 \mu \mathrm{M}$ NU7026 with 1 Gy dose and $10 \mu \mathrm{M}$ NU7026 with 0.5 Gy. The complete growth inhibition (with statistical significance $\mathrm{p} \leq 0.001$ ) was observed after combination of $10 \mu \mathrm{M}$ NU7026 and the dose of 1 Gy (Fig. 1). This combination was chosen for further experiments. 


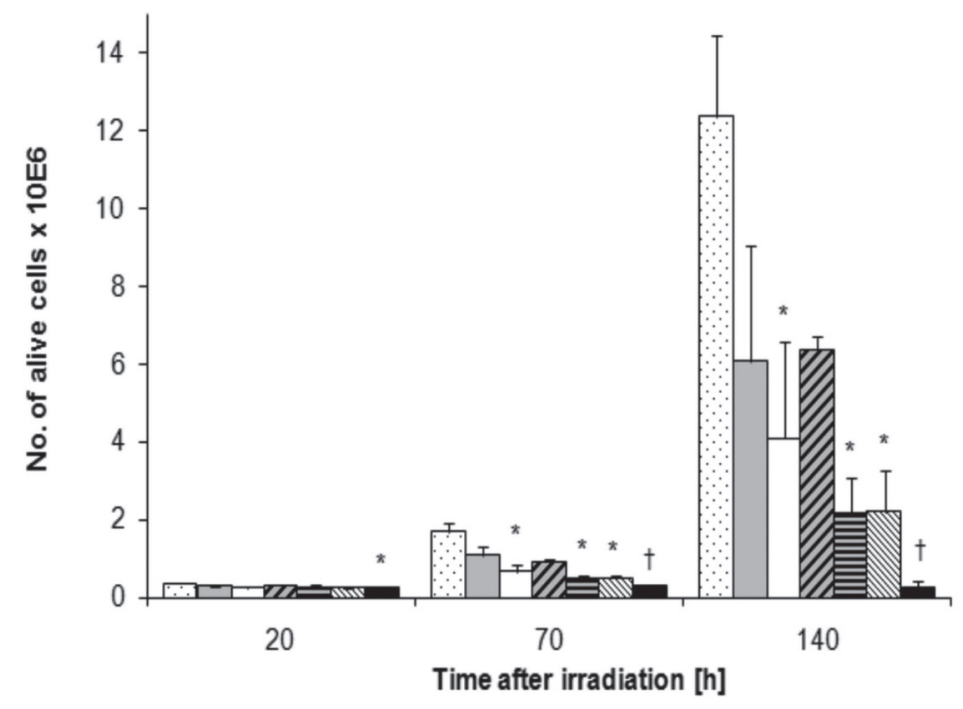

Fig. 1: Proliferation of MOLT-4 cells. Proliferation was measured by trypan blue exclusion technique 20, 70 , and 140 hours after irradiation. The maximal growth-inhibition effect was observed after combination of pre-treatment with $10 \mu \mathrm{M}$ NU7026 and the dose of $1 \mathrm{~Gy}$. Results are the mean of three independent experiments $(* \mathrm{p} \leq 0.025 ; \dagger \mathrm{p} \leq 0.001)$.

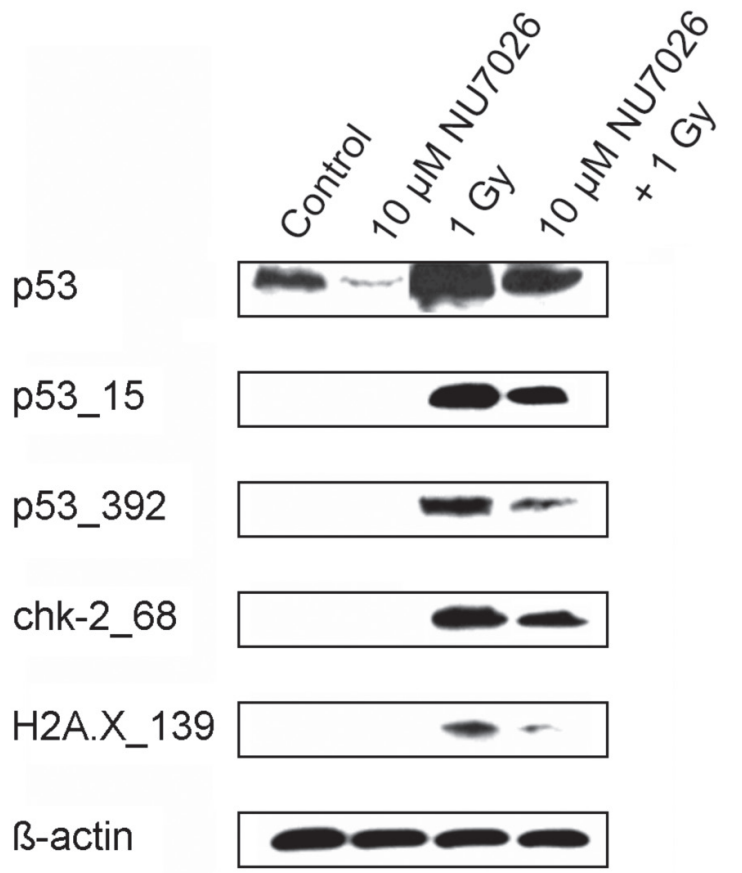

Fig. 2: Western blotting of proteins involved in DNA damage response signalling. MOLT-4 cells were pre-incubated with DNA-PK inhibitor (10 $\mu \mathrm{M}$ NU7026) and exposed to $1 \mathrm{~Gy}$. Whole-cell lysates were analysed $2 \mathrm{~h}$ post-irradiation. Combination of inhibitor and gamma-radiation caused substantial decrease of activated forms of all studied proteins. $\beta$-actin was used as a gel-loading control. A representative blot from at least three independent experiments is shown.

\section{DNA-repair signalling}

We evaluated expression of several proteins involved in DNA repair pathways 2 hours after irradiation. The first one was protein $\mathrm{p} 53$. Its basal amount was detected in the control cells. Amount of p53 decreased in the NU7026-treated cells and it increased after irradiation by the dose of $1 \mathrm{~Gy}$. Pre-treatment of irradiated cells with NU7026 caused partial decrease in p53, though its level was higher compared to the control group (Fig. 2).

We also studied two post-translational modifications of p53 on $\operatorname{Ser}^{15}$ and $\operatorname{Ser}^{392}$. These modifications were not detected in control and NU7026-treated cells, but both serines were phosphorylated after irradiation by $1 \mathrm{~Gy}$ and combination of IR with NU7026 caused their decrease.

We observed the same pattern in phosphorylation of chk-2 on Thr68, which was also detected only in the cells exposed to $1 \mathrm{~Gy}$. Pre-treatment with NU7026 caused slight decrease in phosphorylated chk-2.

Similar results were obtained when we checked for phosphorylated histone H2A.X (on Ser ${ }^{139}$ ). It was detected only in 1 Gy irradiated cells and pre-treatment with NU7026 caused its decrease.

\section{Cell cycle analysis}

We determined the percentage of cells in G1, S, and G2 phase using flow-cytometric analysis of DNA content. We measured cell cycle distribution 24 and 72 hours after irradiation. Cells in the early phase of apoptosis were detected as subG1 peak (i.e. cells with lower amount of DNA than 


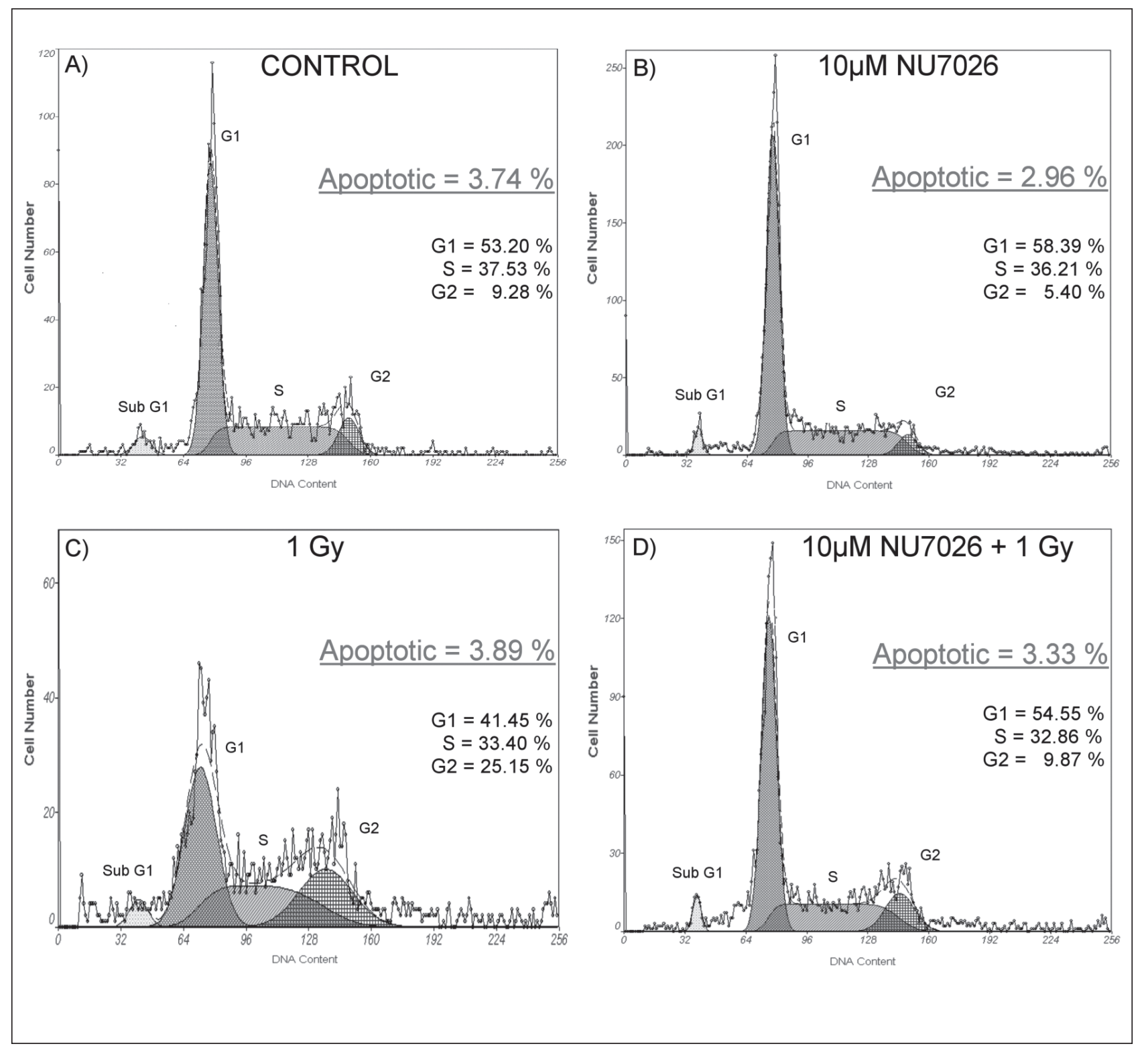

Fig. 3: Flow-cytometric determination of ratio of apoptotic cells and analysis of cell-cycle distribution $24 \mathrm{~h}$ after irradiation. Cells in early phase of apoptosis are detected as subG1 peak (i.e. cells with lower amount of DNA than cells in G1 phase of cell cycle) due to fragmentation and loss of DNA during apoptosis. The percentage of subG1 cells is calculated from the total cell count, distribution of the cells in cell cycle (the percentage of cells in G1, S, G2) is calculated only from the cells in the cycle (excluding subG1). Representative results of one out of three independent experiments are shown.

cells in G1 phase of cell cycle) due to fragmentation and loss of DNA during apoptosis. The percentage of apoptotic cells was unchanged in all experimental groups after 24 hours $(3.74 \%$ in control, $2.96 \%$ in NU7026-treated, $3.89 \%$ in irradiated, and $3.33 \%$ in the group with combination). We observed only modest change in the cell cycle distribution in control and NU7026 treated cells (Fig. 3) but the amount of cells in G2-phase arrest increased when they were exposed solely to the dose of $1 \mathrm{~Gy}$. On the other hand, the combination of inhibitor and IR returned the amount of the cells in G2-phase arrest to the control level. While the cell cycle distribution remained more or less unchanged 72 hours after irradiation, the amount of sub-G1 (i.e. apoptotic) cells increased dramatically in the group with combination of ionising radiation and inhibitor (Fig. 4). 

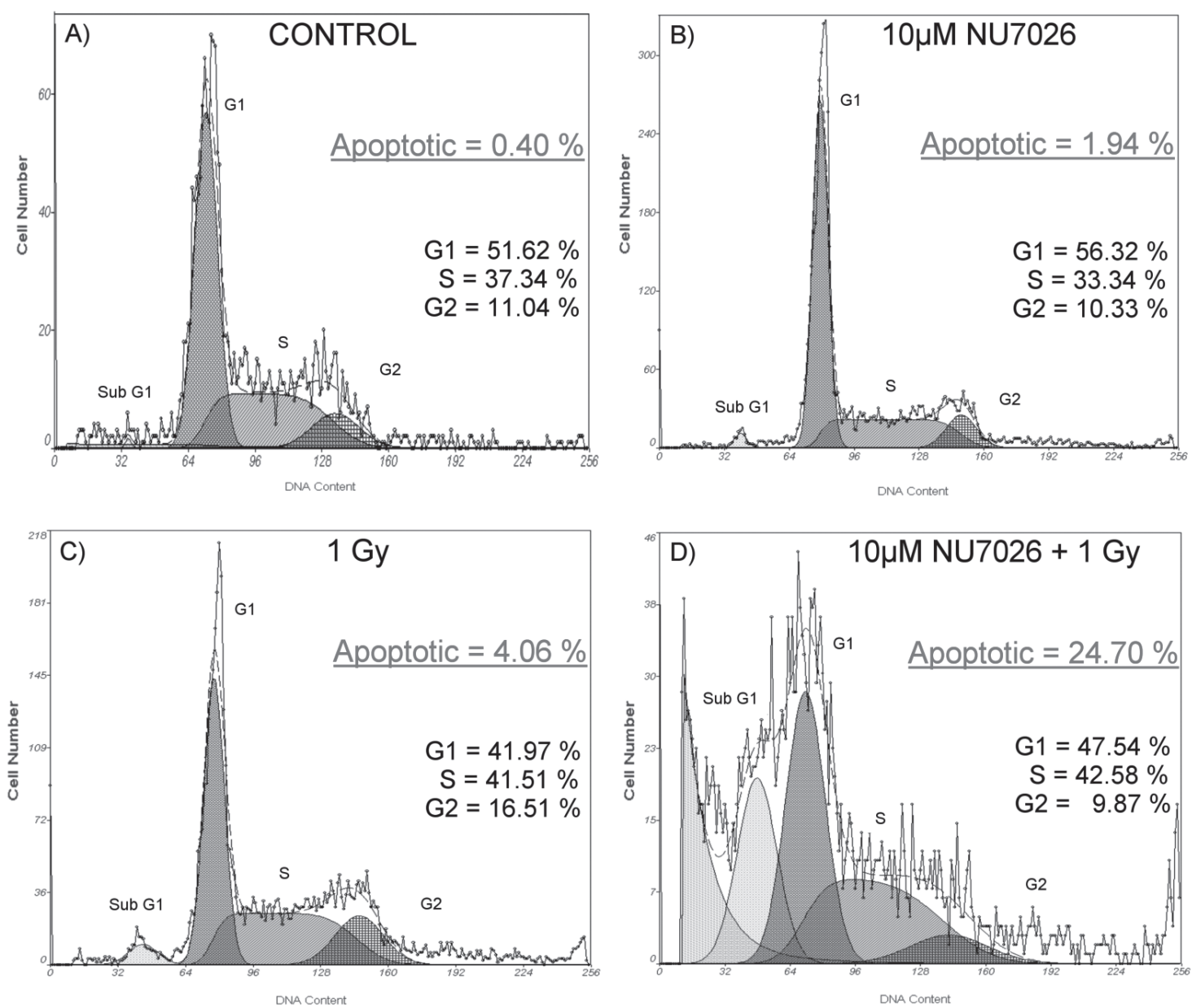

Fig. 4: Flow-cytometric determination of ratio of apoptotic cells and analysis of cell-cycle distribution $72 \mathrm{~h}$ after irradiation. Cells in early phase of apoptosis are detected as subG1 peak (i.e. cells with lower amount of DNA than cells in G1 phase of cell cycle) due to fragmentation and loss of DNA during apoptosis. The percentage of subG1 cells is calculated from the total cell count, distribution of the cells in cell cycle (the percentage of cells in G1, S, G2) is calculated only among the cells in the cycle (excluding subG1). Representative results of one out of three independent experiments are shown.

\section{Discussion}

Signalling pathways monitoring DNA damage play an important role in maintaining genomic integrity and their malfunctions often result in neoplasia. Nowadays, many anti-tumour drugs are developed to cause deactivation or inhibition of components of these pathways in the cancer cells. Although the biochemical mechanisms for repairing DSB in mammalian cells are still not completely understood, substantial progress has been made in the last few years. Undoubtedly, two members the phosphoinositide 3-kinase-like enzyme family, DNA-PK and ATM, play an irreplaceable role in DNA damage repair.

Bakkenist and Kastan (3) in their work on fibroblasts suggested that raise of DSB causes a rapid change of higher-order chromatin structure resulting in ATM activation. Bekker-Jensen et al. (4) reported that ATM is spatially redistributed to DSB-flanking chromatin. In our previous work on human T-lymphocyte leukaemic MOLT-4 cells we have shown ATM/chk-2/p53 signalling pathway to be fully functional upon gamma-irradiation (36).

Active ATM subsequently affects plenty of different targets via phosphorylation and some participate in the cell cycle arrest and apoptosis induction. One of them is chk-2, which is activated by ATM on $\mathrm{Thr}^{68}$. This relatively stable protein responds to ionising radiation throughout the cell cycle and according to Lukas et al. (23) it appears to be inactive in the absence of DNA damage. We also did not find activated chk-2 in NU7026-treated cells and its phosphorylated form was presented only in irradiated cells. On the other hand, 
NU7026 pre-incubation markedly prevented chk-2 phosphorylation after irradiation. It is likely that in spite of the fact that NU7026 affects predominantly DNA-PK than ATM 430 times more (26), it is still capable of chk-2 inhibition, or another (DNA-PK-dependent) mechanism of chk-2 activation exists, however, it has not been reported yet.

Both ATM and chk-2 contribute to an appropriate control of the central mediator of the DNA damage response, protein $\mathrm{p} 53$, which in turn induces cell cycle arrest by up-regulation of $\mathrm{p} 21^{\mathrm{CIP} / \mathrm{WAF}}$ and 14-3-3 protein, activates DNA damage repair pathways, and induces apoptosis (8) (11). Commonly, IR induces apoptosis by activating p53, members of Bcl-2 protein family, and caspases, although p53-independent apoptosis has also been reported (38). We have previously described activation of caspases and pro-apoptotic Bid after gamma-irradiation of MOLT- 4 cells (37). Also in the recent study, p53 was activated since we detected two of its phosphorylations ( $\mathrm{Ser}^{15}$ and $\mathrm{Ser}^{392}$ ) at the $\mathrm{N}$ - and $\mathrm{C}$ - terminus of $\mathrm{p} 53$, respectively, which enable allosteric regulation.

Phosphorylation on $\operatorname{Ser}^{15}$ is crucial for managing DNA repair post-irradiation. Protein p53 is typically a short-lived protein and its degradation is tightly regulated by $\mathrm{Mdm} 2$, p53 negative regulator, which is an E3 ubiquitin ligase (7). Phosphorylation on $\operatorname{Ser}^{15}$ abrogates the ability of Mdm2 to inhibit p53-dependent transactivation (30). Many studies indicate that ATM is indispensable for prolonged half-life of $\mathrm{p} 53$ since it is responsible for this phosphorylation (15, $21,27)$. In contrast, we observed pronounced decrease in Ser $^{15}$ phosphorylation after irradiation via inhibition of DNA-PK by NU7026 in this study. It is supported by the findings of Boehme et al. (6), who reported signalling cascade for the regulation of $\mathrm{p} 53$ on $\mathrm{Ser}^{15}$ in response to IR that involves activation of DNA-PK and subsequently $\mathrm{Akt} / \mathrm{PKB}$ and inactivation of Mdm2 and GSK-3. Additionally, Broehme reported that down-regulation of DNA-PK prevented phosphorylation of Akt/PKB and GSK-3 after exposure to IR and strongly reduced the accumulation of p53, which was apparently ATM-independent since this work has been done on lymphoblasts from patients with the absence of functional ATM.

Phosphorylation on $\mathrm{Ser}^{392}$ localized within carboxyl terminus of $\mathrm{p} 53$ is no less important for radiation response, because it enhances its sequence-specific DNA binding (12). This site on wild-type p53 is phosphorylated by complexes containing casein kinase $2(17,18)$. Keller and colleagues (17) stated that $\operatorname{Ser}^{392}$ phosphorylation occurs after UV- but not gamma-irradiation. Our results proved that gamma-radiation induces $\mathrm{Ser}^{392}$ phosphorylation, since we detected this phosphorylation in irradiated cells and pre-treatment with NU7026 caused its decrease. Taken together, NU7026 inhibited accumulation and activation of p53 via decreased phosphorylation on Ser $^{15}$ and Ser ${ }^{392}$, which possibly leads to abrogation of cell cycle arrest, and subsequent propagation of unrepaired DNA might be one of reasons of increased apoptosis observed.
Very early step in DNA damage response is phosphorylation of histone subtype H2A, class H2A.X (28). Phosphorylated H2A.X on $\operatorname{Ser}^{139}(\gamma \mathrm{H} 2 \mathrm{~A}$.X) can be visualized by suitable antibody via immunofluorescence as a discrete focus and it is localized in the range of $2 \times 10^{6}$ bases from DSB (29). We recently reported flow-cytometric determination of $\gamma \mathrm{H} 2 \mathrm{~A}$.X as a perspective biodosimetric indicator in peripheral lymphocytes of whole-body-irradiated rats by the dose 1-10 Gy (14). DSB induce histone H2A.X phosphorylation, which is associated with the recruitment of repair factors and $\gamma \mathrm{H} 2 \mathrm{~A} . \mathrm{X}$ is critical for facilitating the assembly of specific DNA-repair complexes on damaged DNA (9). Stiff et al. (34) concluded that under most normal growth conditions, IR-induced H2AX phosphorylation can be carried out by ATM and DNA-PK in a redundant, overlapping manner. In contrast, DNA-PK cannot phosphorylate other proteins involved in the checkpoint response. However, by phosphorylating H2A.X, DNA-PK can contribute to the presence of the damage response proteins $\mathrm{MDC} 1$ and 53BP1 at the site of the DSB. Our results are in consistence with these findings since NU7026 inhibited DNA-PK and we observed decreased radiation-induced $\mathrm{H} 2 \mathrm{~A}$.X phosphorylation when compared to solely irradiated cells.

DNA-PK is a crucial component of non-homologous end-joining and key determinant of radio- and chemoresistance (40). Lack of DNA-PK causes defective DSB repair and radio-sensitisation. In addition to its role in DNA repair, DNA-PK is also involved in apoptosis. Once gamma-radiation induces DSB, the DNA-PK complex senses and repairs them; on the other hand, when DNA damage is excessive, DNA-PK induces apoptosis (5).

When apoptotic stimuli are released, the key regulators of cell death process are members of Bcl-2 protein family (35). Myeloid cell leukemia 1 protein, Mcl-1, functions among the proteins, which maintain mitochondrial integrity via interaction with pro-apoptotic partners after gamma-irradiation (32). Interestingly, Mcl-1 could act as an adaptor protein essential in ATR-mediated checkpoint kinase-1 phosphorylation (16). In our previous work on MOLT-4 cells (37) we found the amount of Mcl-1 initially increased after irradiation by sublethal but not by lethal dose and later (when apoptosis occurred) its dose-dependent decrease was associated with apoptosis induction. Surprisingly, in the recent experiments, 24 hours after irradiation we expected decrease in Mcl-1 caused by the combination of IR and NU7026, but we did not observe any substantial decrease (data not shown), suggesting that Mcl-1 regulation occurs in DNA-PK-independent manner or that the effect is delayed. Therefore we evaluated apoptosis by flow-cytometric analysis of DNA content. Twenty four hours after irradiation the rate of apoptotic cells was similar (around 3\%) in all of the groups but 72 hours after irradiation there was a pronounced and significant effect of combination of inhibitor and radiation and increased apoptosis was measured 
(24\%). Willmore and colleagues (41) reported that $10 \mu \mathrm{M}$ NU7026 potentiated the growth inhibition of topoisomerase II poisons and that NU7026 alone had no effect on cell cycle distribution, but etoposide-induced accumulation in G2/M was increased by NU7026. By contrast, in our experiments the radiation-induced accumulation in G2/M was decreased by NU7026. On the other hand, Zhu and Gooderham (42) observed in human lung adenocarcinoma A549 cells using cryptolepine, a DNA-damaging agent, that $10 \mu \mathrm{M}$ NU7026 showed neither induction of cell cycle arrest and apoptosis nor the expression of p53 and p21, while Amrein et al. (1) reported that NU7026 increases chlorambucil-induced G2/M arrest and number of DSBs in chronic lymphocytic leukaemia. Apparently, it is expected that the effect of NU7026 depends on the type DNA-damaging agent and the type of cells used in a particular study.

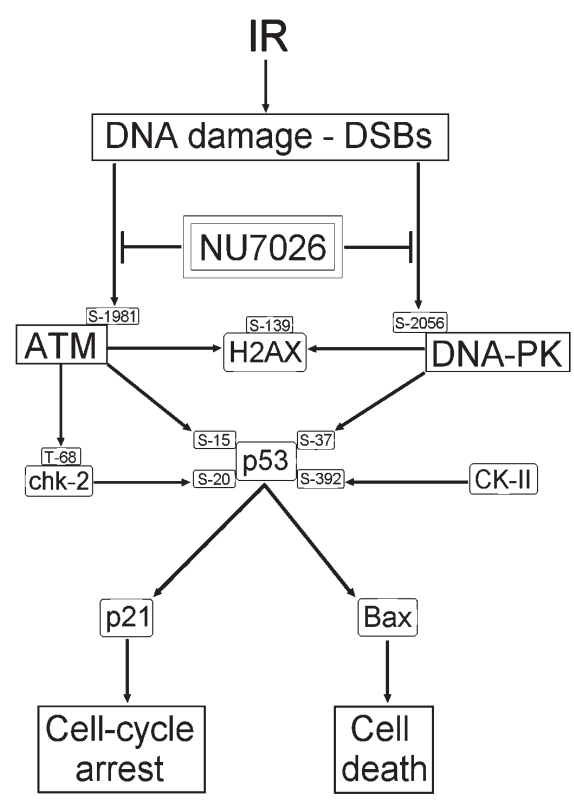

Fig. 5: DNA-damage response pathways targeted by NU7026. Presence of IR-induced DBS activates two main kinases ATM and DNA-PK by autophosphorylation. ATM and DNA-PK are inhibited by NU7026. Both of them phosphorylate histon H2A.X on Ser 139 in overlapping and independent manner. Another core target is genome guardian - p53. It is phosphorylated directly by ATM on Ser 15 or indirectly via chk-2 on Ser 20. DNAPK phosphorylates p53 on Ser 37 and casein-kinase II phosphorylates it on Ser 392. All these post-translational modifications contribute to stabilization of p53 and facilitate its transcriptional function (see text). p53 either induces cell cycle arrest via up-regulation of p21 in order to provide sufficient time-window for DNA-repair processes or (in the case of excessive DNA-damage) up-regulates pro-apoptotic factors, which subsequently results into induction of cell death.

\section{Conclusion}

Radiation and chemotherapy are two important strategies for cancer treatment. We used DNA repair inhibitor NU7026 in the concentration targeting preferably DNA$\mathrm{PK}$, to prevent ionizing radiation-induced DSB repair. Post-translational modifications of some DNA-PK and/ or ATM downstream effectors (p53, chk-2, and H2A.X) showed substantial decrease, i.e. they were less activated. This led to subdued DNA repair and consequently to increased apoptosis induction.

Taken together, our results indicate that DNA-PK/ATM inhibition by NU7026 concurrent with ionising radiation may be an effective therapeutic modality for radio-sensitisation of leukaemic cells.

\section{Abbreviations}

ATM, ataxia-telangiectasia mutated kinase; DNA-PK, DNA-dependent protein kinase; IR, ionising radiation; $\mathrm{p} 53$, TP53 tumour suppressor

\section{Acknowledgement}

This work was supported by Ministry of Defence, Czech Republic (A long-term organization development plan 1011). The authors would like to thank Bc. Lenka Mervartová and Mrs. Jaroslava Prokešová for their excellent technical support.

\section{Declaration of interest}

The authors report no conflicts of interest. The authors alone are responsible for the content and writing of the paper.

\section{References}

1. Amrein L, Loignon M, Goulet AC, Dunn M, Jean-Claude B, Aloyz R, Panasci L. Chlorambucil cytotoxicity in malignant B lymphocytes is synergistically increased by 2-(morpholin-4-yl)-benzo(h)chomen-4-one (NU7026)-mediated inhibition of DNA double-strand break repair via inhibition of DNA-dependent protein kinase. J Pharmacol Exp Ther 2007; 321: 848-855.

2. Anderson CW, Carter TH. The DNA-activated protein kinase - DNA-PK. Curr Top Microbiol Immunol 1996; 217: 91-111.

3. Bakkenist C, Kastan MB. DNA damage activates ATM through intermolecular autophosphorylation and dimmer dissociation. Nature 2003; 421: 499-506.

4. Bekker-Jensen S, Lukas C, Kitagawa R, Melander F, Kastan MB, Bartek J, Lukas J. Spatial organization of the mammalian genome surveillance machinery in response to DNA strand breaks. J Cell Biol 2006; 173: 195-206.

5. Bernstein C, Bernstein H, Payne CM, Garewal H. DNA repair/pro-apoptotic dual-role proteins in five major DNA repair pathways: fail-safe protection against carcinogenesis. Mutat Res 2002; 511: 145-178.

6. Boehme KA, Kulikov R, Blattner C. p53 stabilization in response to DNA damage requires Akt/PKB and DNA-PK. Proc Natl Acad Sci USA 2008; 105 : $7785-7790$.

7. Brooks CL, Gu W. p53 ubiquitination: Mdm2 and beyond. Mol. Cell 2006; 21 : 307-315.

8. Caspari T. How to activate p53. Curr Biol 2000; 10: R315-R317.

9. Celeste A, Petersen S, Romanienko PJ, Fernandez-Capetillo O, Chen HT, Sedelnikova OA, Reina-San-Martin B, Coppola V, Meffre E, Difilippantonio MJ, Redon C, Pilch DR, Olaru A, Eckhaus M, CameriniOtero RD, Tessarollo L, Livak F, Manova K, Bonner WM, Nussenzweig MC, 
Nussenzweig A. Genomic instability in mice lacking histone H2AX. Science 2002; 296: 922-927.

10. Chu G. Double strand break repair. J Biol Chem 1997; 272: 24097-24100.

11. Colman MS, Afshari CA, Barrett JC. Regulation of p 53 stability and activity in response to genotoxic stress. Mutat Res 200; 462: 179-188.

12. Criswell T, Leskov K, Miyamoto S, Luo G, Boothman DA. Transcription factor activated in mammalian cells after clinically relevant doses of ionizing radiation. Oncogene $2003 ; 22$ : 5813-5827.

13. Griffin RJ, Fontana G, Golding BT, Guiard S, Hardcastle IR, Leahy JJ, Martin N, Richardson C, Rigoreau L, Stockley M, Smith GC. Selective benzopyranone and pyrimido(2,1-a)isoquiolin-4-one inhibitors of DNA-dependent protein kinase: synthesis, structure-activity studies, and radiosensitisation of a human tumor cell line in vitro. J Med Chem 2005; 48: 569-585.

14. Havelek R, Řezáčová M, Šinkorová Z, Zárybnická L, Tichý A, Vávrová J. Phosphorylation of histone $\mathrm{H} 2 \mathrm{AX}$ as an indicator of received dose of gamma radiation after whole-body irradiation of rats. Acta Veterinaria Brno 2011; 80: 113-118.

15. Helt CE, Cliby WA, Keng PC, Bambara RA, O'Reilly MA. Ataxia telangiectasia mutated (ATM) and ATM and Rad3-related protein exhibit selective target specificities in response to different forms of DNA damage. J Biol Chem 2005; 280 : $1186-1192$.

16. Jamil S, Mojtabavi S, Hojabrpour P, Cheah S, Duronio V. An essential role for MCL-1 in ATR-mediated CHK1 phosphorylation. Mol Biol Cell 2005; 19: 3212-3220.

17. Keller DM, Zeng X, Wang Y, Zhang QH, Kapoor M, Shu H, Goodman R, Lozano G, Zhao Y, Lu H. DNA damage-induced p53 serine 392 kinase complex contain CK2, hSpt16, and SSRP1. Mol Cell 2001; 7: 283-292.

18. Keller DM, Lu H. p53 serine 392 phosphorylation increases after UV through induction of the assembly of the CK2.hSPT16.SSRP1 complex. J Biol Chem 2002; 277: 50206-50213.

19. Khanna KK, Lavin MF, Jackson SP, Mulhern TD. ATM, a central controller of cellular responses to DNA damage. Cell Death Differ 2001; 8: 1052-1065.

20. Lavin MF, Khanna KK, Beamish H, Spring K, Watters D, Shiloh Y. Relationship of the ataxia-telangiectasia protein ATM to phosphoinositide 3-kinase. Trend Biochem Sci 1995; 20: 382-383.

21. Lavin MF, Gueven N. The complexity of p53 stabilization and activation. Cell Death Differ 2006; 13: 941-950.

22. Leber R, Wise TW, Mizuta R, Meek K. The XRCC4 gene product is a target fo and interacts with the DNA-dependent protein kinase. J Biol Chem 1998; 273 : 1794-1801.

23. Lukas C, Bartkova J, Latella L, Falck J, Mailand N, Schroeder T, Sehested M, Lukas J, Bartek J. DNA damage-activated kinase Chk2 is independent of proliferation or differentiation yet correlates with tissue biology. Cancer Res 2001; 61 4990-4993.

24. Matsuoka S, Rotman G, Ogawa A, Shiloh Y, Tamai K, Elledge SJ. Ataxia telangiectasia-mutated phosphorylates Chk2 in vivo and in vitro. Proc Natl Acad Sci USA 200; 97: 10389-10394.

25. Maya R, Balass M, Kim ST, Shkedy D, Leal JF, Shifman O, Moas M, Buschmann T, Ronai Z, Shiloh Y, Kastan MB, Katzir E, Oren M. ATM-dependent phosphorylation of Mdm2 on serine 395: Role in p53 activation by DNA damage. Genes Devel 2001; 15: 1067-1077.

26. Nutley BP, Smith NF, Hayes A, Kelland LR, Brunton L, Golding BT, Smit GC, Martin NM, Workman P, Raynaud FI. Preclinical pharmacokinetics and metabolism of a novel prototype DNA-PK inhibitor NU7026. Br J Cancer 2005; 93: 1011-1018.

27. Riley T, Sontag E, Chen P, Levine A. Transcriptional control of human p53-regulated genes. Nat. Rev. Mol Cell Biol 2008; 9: 402-412.

28. Rogakou EP, Pilch DR, Orr AH, Ivanova VS, Bonner WM. DNA double-stranded breaks induce histone H2A.X phosphorylation on serine 139. J Biol Chem 1998; 273: $5858-5869$.

29. Rogakou EP, Boon C, Redon C, Bonner WM. Megabase chromatin domains involved in DNA double-strand breaks in vivo. J Cell Biol 1999; 146: 905-916.

30. Shieh SY, Ikeda M, Taya Y, Prives C. DNA damage-induced phosphorylation of p53 alleviates inhibition by MDM2. Cell 1997; 91: 325-334.

31. Shiloh Y. The ATM-mediated DNA-damage response: taking shape. Trends Biochem Sci 2006; 31: 402-410.

32. Skvara H, Thallinger C, Wacheck V, Monia BP, Pehamberger H, Jansen B, Selze E. Mcl-1 blocks radiation-induced apoptosis and inhibits clonogenic cell death Anticancer Res $2005 ; 25: 2697-2703$.

33. Smith GC, Jackson SP. The DNA-dependent protein kinase. Genes Devel 1999; 13: 916-934

34. Stiff T, O'Driscoll M, Rief N, Iwabuchi K, Löbrich M, Jeggo PA. ATM and DNA-PK function redundantly to phosphorylate H2AX after exposure to ionizing radiation. Cancer Res 2004; 64: 2390-2396.

35 . Tichý A. Apoptotic machinery: the Bcl-2 family proteins in the role of inspectors and superintendents. Acta Medica (Hradec Kralove) 2006; 49: 13-18.

36. Tichý A, Záškodová D, Řezáčová M, Vávrová J, Vokurková D, Pejchal J, Vilasová Z, Cerman J, Österreicher J. Gamma-radiation-induced ATM-dependen signalling in human T-lymphocyte leukemic cells, MOLT-4 2007; Acta Biochim Pol. 54: 281-287.

37. Tichý A, Záškodová D, Pejchal J, Řezáčová M, Österreicher J, Vávrová J, Cerman J. Gamma irradiation of human leukaemic cells HL-60 and MOLT-4 induces decrease in Mcl-1 and Bid, release of cytochrome c, and activation of caspase- 8 and caspase-9. Int J Radiat. Biol 2008; 84: 523-530.

38. Verheij M, Bartelink H. Radiation-induced apoptosis. Cell Tissue Res 2000; 301 $133-142$.

39. Veuger SJ, Curtin NJ, Richardson CJ, Smith GC, Durkacz BW. Radiosensitization and DNA repair inhibition by the combined use of novel inhibitors of DNA-dependent protein kinase and poly(ADP-ribose) polymerase-1. Cancer Res 2003; 63: 6008-6015.

40. Veuger SJ, Curtin NJ, Smith GC, Durkacz BW. Effects of novel inhibitors of poly(ADP-ribose) polymerase-1 and the DNA-dependent protein kinase on enzyme activities and DNA repair. Oncogene 2004; 23: 7322-7329.

41. Willmore E, de Caux S, Sunter NJ, Tilby MJ, Jackson GH, Austin CA, Durkacz BW. A novel DNA-dependent protein kinase inhibitor, NU7026, potentiates the cytotoxicity of topoisomerase II poisons used in the treatment of leukemia. Blood 2004; 103: 4659-4665.

42. Zhu H, Gooderham NJ. Mechanisms of induction of cell cycle arrest and cell death by cryptolepine in human lung adenocarcinoma a549 cells. Toxicol Sci 2006; 91: 132-139.

Received: $26 / 10 / 2011$

Accepted in revised form: 09/05/2012

\section{Corresponding author:}

Aleš Tichý, Department of Radiobiology, Faculty of Health Sciences, University of Defence, Třebešská 1575, 50001 Hradec Králové, Czech Republic; e-mail: tichy@pmfhk.cz 